POLITYKA ENERGETYCZNA - ENERGY POLICY JOURNAL

$2021 \downarrow$ Volume $24 \downarrow$ Issue $4 \uparrow 153-164$

DOI: $10.33223 / \mathrm{epj} / 144935$

Oleksandr DluhopolskyI ${ }^{1}$, Vasyl Brych ${ }^{2}$, Olena Borysiak ${ }^{3}$, Mykhailo Fedirko ${ }^{4}$, Nataliya DzIUBANOvsKA ${ }^{5}$, Nataliya HALYsh $^{6}$

\title{
Modeling the environmental and economic effect of value added created in the energy service market
}

ABSTRACT: The introduction of energy conservation and resource conservation measures has a positive impact on the environment and is one of the components of sustainable development at the macro level. In turn, at the micro level, such measures lead to a systematic decrease in the production costs of companies and thereby expand their economic and financial security. This article is devoted to the development of methodological tools for modeling the environmental and economic effect of added value created in the energy service market. For this, the peculiarities and components of the energy service contract have been identified. It has been established that one of the indicators of the conclusion of such a contract is the indicator of energy efficiency and environmental friendliness of measures in the structure of the added value of an energy service company. An analysis of existing

$\triangle$ Corresponding Author: Oleksandr Dluhopolskyi; e-mail: dlugopolsky77@gmail.com

1 West Ukrainian National University, Ternopil Volodymyr Hnatiuk National Pedagogical University, Ukraine; ORCID iD: 0000-0002-2040-8762; e-mail: dlugopolsky77@gmail.com

2 West Ukrainian National University, Ukraine; ORCID iD: 0000-0002-4277-5213; e-mail: v.brych@wunu.edu.ua

3 West Ukrainian National University, Ukraine; ORCID iD: 0000-0003-4818-8068; e-mail: o.borysiak@wunu.edu.ua

4 West Ukrainian National University, Ukraine; ORCID iD: 0000-0001-8244-3478; e-mail: m.fedirko@wunu.edu.ua

5 West Ukrainian National University, Ukraine; ORCID iD: 0000-0002-8441-5216; e-mail: n.dziubanovska@wunu. edu.ua

${ }^{6}$ West Ukrainian National University, Ukraine; ORCID iD: 0000-0002-8538-823X; e-mail: n.halysh@wunu.edu.ua

2021. The Author(s). This is an open-access article distributed under the terms of the Creative Commons Attribution-ShareAlike International License (CC BY-SA 4.0, http://creativecommons.org/licenses/by-sa/4.0/), which permits use, distribution, and reproduction in any medium, provided that the Article is properly cited. 
models of added value created in the energy service market is carried out. A model of economic value added is taken as the basis for modeling the ecological and economic effect of added value created in the energy service market. The rationale is that such value-added is a modification of the economic profit indicator, which measures the financial result of a company, considering not only accounting costs but also the opportunity costs of invested capital for energy efficiency and environmental measures.

KEYWORDS: sustainable development, green energy, value added, energy market, energy service companies (ESCO)

\section{Introduction}

Energy efficiency and associated resource conservation and anthropogenic impact on the environment are the most relevant factors in the paradigm of the sustainable development of modern society. It manifests itself both at the macroeconomic level and at the micro-level, which means the sustainable development of modern business, which provides competitive advantages for companies in a market environment that is changing rapidly. In particular, the introduction of energy conservation and resource conservation measures at the micro level for companies is expressed by a decrease in the amounts of cohesive payments for the use of natural resources, payments for emissions and discharges to environmental objects, the formation of their green image and, due to this, in the improvement of their market positions.

As business practice shows, manufacturing companies are not always able to independently determine the available reserves of energy conservation and resource conservation and find the best ways to implement them in environmental and economic terms. As a rule, this is due to insufficient qualifications of personnel on energy conservation and resource conservation, lack of motivations for such activities and lack of funds for the implementation of such activities. In this regard, there is an objective need for the development of the energy service market, which provides qualified services for the development and implementation of measures and the preservation of various types of production resources, primarily energy resources.

Therefore, the problem arises of assessing the efficiency of the energy service market, which can be determined through the efficiency of the activities of its main subjects: manufacturing companies as customers for energy services and energy service companies as its executors. 


\section{Literature review}

Aspects of the formation and development of the energy service market are considered in the works of both Ukrainian and international scientists, in particular the energy service companies in the market of resource-saving goods and services (Sotnik and Mazin 2015; Report extract ESCO contracts 2021; Fraser and Montross 1998), the assessment of energy service companies (Peñate-Valentín et al. 2021; Vence and Pereira 2019), the innovative development management of energy service companies based on digital and sustainability approaches (Borysova et al. 2021; Urge-Vorsatz et al. 2007; Kovtoniuk et al. 2021; Koziuk et al. 2020).

The resources (Boza-Kiss et al. 2019; Bertoldi et al. 2019) describe an evidence-based approach to the European policymaking process in the field of the energy service market. The authors discussed the challenges of the market development of energy service companies (ESCOs) in European Member States.

Models of the added value of companies have been studied by Davydov (2017), Volkov (2008), Milinchuk (2017), Romanenko (2013), and many others. In their research, they focus on the economic content of value added, regardless of the type of economic activity of companies and the specifics of the market in which they operate. In the concept paradigm of sustainable development, along with its economic component, two other components acquire great importance: the ecological and the social. In scientific research, this issue is not given due attention. In addition, the authors clarified the peculiarities of the models of added value of companies within the framework of the introduction of value-oriented management, depending on their type of economic activity.

\section{Methodology and research methods}

An ESCO can finance a project in several ways: with its own funds, with a bank loan, through leasing or through capital investments. The use of the performance indicator (NPV) does not fully take into account accounting standards, primarily in terms of accounting for income and expenses. The next significant drawback of this indicator is the impossibility of its application in the system of value-oriented management of companies, including companies involved in the energy service market. As a result, the indicator of added value was proposed to assess the efficiency of an energy service contract in the current research.

To evaluate value-added models created in the energy service market and to choose methodological tools, the following models of added value were analyzed (Davydov 2017; Brych et al. 2021a; 2021b): 
the economic value-added models:

$$
E V A=N O P A T-W A C C \times I C
$$

where:

EVA - economic value added,

NOPAT - net operating profit after income tax, but before interest,

WACC - weighted average cost of capital,

IC $\quad-$ invested capital;

$\checkmark$ the market value added (MVA) model:

$$
M V A=M V D+M C-T C
$$

where:

$M V D$ - the market value of the debt,

$M C$ - market capitalization,

$T C \quad$ - the total amount of capital;

the cash flow return on investment (CFROI) model:

$$
C F R O I=\frac{C F^{a d j}}{C I^{a d j}}
$$

where:

$C F^{a d j}$ - inflation adjusted cash inflows,

$C I^{a d j}$ - inflation adjusted cash investments.

Thus, to sum up the above, the model of added value created in the energy service market can be based on an energy service contract, which should be considered as an investment project, both on the part of the ESCO and on the part of the customer company.

The purpose of this study is to develop a methodological toolkit for modeling the environmental and economic effects of added value created in the energy service market. 


\section{Results}

According to the conceptual apparatus introduced by the Law of Ukraine "On the introduction of new investment opportunities, ensuring the rights and legitimate interests of business entities for large-scale energy modernization" (Law of Ukraine 2015), energy service is defined as a set of technical, organizational energy-saving strategies (energy efficient) and other measures aimed at reducing energy service consumption and/or expenses for the payment of fuel and energy resources and/or housing and communal services in comparison with consumption (expenses) in the absence of such measures.

The specified set of measures is being implemented within the framework of an energy service agreement, the subject of which, according to the requirements of the law, is the implementation of an energy service by an energy service contractor, payment for which is at the expense of the reduction in consumption and/or expenses for payment of fuel and energy resources and/or housing and communal services achieved as a result of the implementation of the energy service compared to consumption (costs) in the absence of such activities.

Within the framework of the energy service project/contract, the contractor (ESCO) attracts funds (own, credit, etc.) based on the results of an energy audit (conducted by them or the customer) determines and implements the most effective measures to reduce the consumption of energy resources at the customer's facility, and also guarantees the achievement of corresponding cost savings.

At the same time, during the term of the contract, the customer pays the contractor a proportion of (according to the legislation) the funds saved on payment for energy resources and/or housing and communal services as a result of energy services. After the end of the contract, the entire amount of the savings and the installed equipment become the property of the customer. Moreover, the energy service contract is terminated early if the total amount of payments made in favor of the contractor under the ESCO contract has reached the price of such an agreement.

One of the important factors stimulating the conclusion of energy service contracts is that payments to the contractor are made only on the basis of the verification of the achievement of the savings specified in the contract. At the same time, in the context of considering this issue, it is important to determine the level of use of innovative approaches to the energy service, in particular, the introduction of smart technologies (Liakhovych et al. 2021), digital marketing tools to ensure promotion and communication in the energy service market (Van Der Kam et al. 2019; Brych et al. 2020), and innovative approaches to marketing management of energy service companies and energy enterprises (Maki et al. 2021; Borysiak and Brych 2021). The model of the environmental and economic effect of added value created in the energy service market can be based on an energy service contract.

The concept of market value-added has several limitations: $M V A$ calculation is possible only in relation to enterprises whose shares are traded on the stock market (thus they have market values); market value added can be determined for the enterprise (business) as a whole, and not for 
individual structural divisions and investment projects (in relation to them, there are no market share prices).

Value added can be written using the economic value added formula $E V A$. It is a modification of the economic profit indicator which measures the financial result of the company's activities taking into account not only accounting costs but also the opportunity costs of invested capital in energy efficiency and environmental measures:

$$
N O P A T=E B I T_{\text {on }} \cdot\left(1-K_{\text {on }}\right)
$$

where:

$$
\begin{array}{ll}
E_{\text {BIT }} \quad- & \text { profit before interest and income tax, } \\
K_{\text {on }}- & \text { income tax rate, } \\
\text { EBIT }_{\text {on }}=C F_{t}- & \text { cash flow in the time period } T, \text { which is generated by the investment project } \\
& (\text { energy efficiency measures in the time period } T):
\end{array}
$$

$$
E V A=\sum_{t=1}^{T} \frac{C F_{t}}{(1+R)^{t}}\left(1-K_{o n}\right)-\sum_{t=1}^{T} W A C C \cdot I C_{t}
$$

If $\alpha$ is the contract price (i.e. a part of the cash flow from resource savings that is paid to the ESCO), then $(1-\alpha)$ is the part of the cash flow that remains in the customer's company; $d$ is the share of capital invested in the ESCO project, then $(1-d)$ is the share of capital invested in the project by the customer.

Then the added value is created:

1) ESCO:

$$
E V A_{E S C O}=\sum_{t=1}^{T} \frac{\alpha C F_{t}}{(1+R)^{t}}\left(1-K_{O \Pi}\right)-\sum_{t=1}^{T} d \cdot W A C C \cdot I C_{t}
$$

2) Customer:

$$
E V A_{\text {cusromer }}=\sum_{t=1}^{T}(1-\alpha) \frac{C F_{t}}{(1+R)^{t}}\left(1-K_{\text {OП }}\right)-\sum_{t=1}^{T}(1-d) \cdot W A C C \cdot I C_{t}
$$

Total added value from the project:

$$
\begin{aligned}
& E V A_{\text {general }}=E V A_{E S C O}+E V A_{\text {customer }}=\sum_{t=1}^{T} \frac{\alpha C F_{t}}{(1+R)^{t}}\left(1-K_{\text {OП }}\right)-\sum_{t=1}^{T} d \cdot W A C C \cdot I C_{t}+ \\
& +\sum_{t=1}^{T}(1-\alpha) \frac{C F_{t}}{(1+R)^{t}}\left(1-K_{\text {OП }}\right)-\sum_{t=1}^{T}(1-d) \cdot W A C C \cdot I C_{t}
\end{aligned}
$$


where:

$T$ - the project implementation period in years.

The objective function for optimization will have the form $E V A_{\text {general }} \rightarrow$ max.

By restrictions, $E V A_{E S C O}\left(\alpha, d, T, K_{\text {on }}, W A C C, R\right) \geq 0, E V A_{\text {customer }}(\alpha, \mathrm{d}, \mathrm{T}, \mathrm{Kon}, \mathrm{WACC}, \mathrm{R})$ $\geq 0$.

Options for independent variables for calculation:

1) $\alpha=0.85 ; d=1 ; R=10.5 ; K_{O \Pi}=0.18 ; T-$ equal to the payback period; $W A C C=0.05(5 \%)$;

2) $\alpha=0.85 ; d=0.5 ; R=10.5 ; K_{O \Pi}=0.18 ; T=(8.3 ; 15.1)$; WACC $=0.055 \%$.

Let us investigate the dependence of the $E V A_{\text {general }}$ function on the independent variable $\alpha$ and consider how the values of the EVA ESCO and EVA $A_{\text {customer }}$ functions will change in this case. For example, as an energy efficient measure, we use data on investment, savings, and the payback period for replacing window and door blocks, thermal insulation and installation of ITP (Table 1). Input values for other parameters are $d=1 ; T=8 ; K_{\text {on }}=18 \%, W A C C=5 \%, R=10.5 \%$.

TABLE 1. Evaluating the effectiveness of the project

TABELA 1. Ocena efektywności projektu

\begin{tabular}{|c|l|c|c|c|}
\hline \multicolumn{2}{|c|}{ Energy efficient measures } & Investments & Saving & Payback \\
\cline { 3 - 5 } & thousand, UAH & thousand, UAH & years \\
\hline 1. & $\begin{array}{l}\text { Replacement of window } \\
\text { and door blocks }\end{array}$ & $1,093,078$ & 131,000 & 8.3 \\
\hline 2. & Thermal insulation & $5,526,593$ & 366,916 & 15.1 \\
\hline 3. & Installation of ITP & $1,939,884$ & $1,163,747$ & 1.7 \\
\hline
\end{tabular}

Source: compiled by the authors.

Let us consider how the contract price ( $\alpha$ ) affects the values of the functions $E V A_{\text {general }}, E V A$ $E S C O$ and $E V A_{\text {customer }}$, or to be more precise, how a part of the cash flow from resource saving which is paid to the ESCO and a part of the cash flow which remains in the customer's company will be changed. After carrying out the corresponding calculations, we obtain the results presented in Table 2.

In addition to the numerical expression of the dependencies of $E V A_{\text {general }}, E V A_{E S C O}$ and $E V A_{\text {customer }}$ on the contract price, let us consider a graphic illustration of the obtained results. In Figure 1, we can clearly see that with an increase in the variable $\alpha$, a part of the cash flow from resource savings, which is paid to the ESCO also increases, while a part of the cash flow that remains in the customer's company will decrease and is equal to 0 at $\alpha=1$. This indicates that favorable conditions for participation in projects for both the $E S C O$ and the customer will be the point of intersection of the two functions $E V A_{E S C O}$ and $E V A_{\text {customer }}$ or close to it $(\alpha \approx 0.55)$.

Linear dependences of the functions $E V A_{E S C O}$ and $E V A_{\text {customer }}$ on the contract price are described by the equations of the straight lines:

$\checkmark E V A_{E S C O}: y=670214 x-60119$;

$\downarrow$ EVA customer $: y=-670214 x+670214$. 
TABLE 2. The results of calculating the values of the $E V A_{\text {general }}, E V A_{E S C O}$ and $E V A_{\text {customer }}$ functions depending on the change in the contract price $(\alpha)$

TABELA 2. Wyniki obliczenia wartości funkcji $E V A_{\text {general }}, E V A_{E S C O}$ i $E V A_{\text {customer }}$ w zależności od zmiany ceny umownej $(\alpha)$

\begin{tabular}{|c|c|c|c|}
\hline Contract price $(\alpha)$ & EVA $A_{\text {general }}$ & $E V A_{E S C O}$ & EVA $A_{\text {customer }}$ \\
\hline 0 & $610,094.27$ & $-60,119.29$ & $670,213.56$ \\
\hline 0.05 & $610,094.27$ & $-26,608.61$ & $636,702.88$ \\
\hline 0.1 & $610,094.27$ & $6,902.0663$ & $603,192.21$ \\
\hline 0.15 & $610,094.27$ & $40,412.744$ & $569,681.53$ \\
\hline 0.2 & $610,094.27$ & $73,923.423$ & $536,170.85$ \\
\hline 0.25 & $610,094.27$ & $107,434.1$ & $502,660.17$ \\
\hline 0.3 & $610,094.27$ & $140,944.78$ & $469,149.49$ \\
\hline 0.35 & $610,094.27$ & $174,455.46$ & $435,638.82$ \\
\hline 0.4 & $610,094.27$ & $207,966.14$ & $402,128.14$ \\
\hline 0.45 & $610,094.27$ & $241,476.81$ & $368,617.46$ \\
\hline 0.5 & $610,094.27$ & $274,987.49$ & $335,106.78$ \\
\hline 0.55 & $610,094.27$ & $308,498.17$ & $301,596.1$ \\
\hline 0.6 & $610,094.27$ & $342,008.85$ & $268,085.43$ \\
\hline 0.65 & $610,094.27$ & $375,519.53$ & $234,574.75$ \\
\hline 0.7 & $610,094.27$ & $409,030.2$ & $201,064.07$ \\
\hline 0.75 & $610,094.27$ & $442,540.88$ & $167,553.39$ \\
\hline 0.8 & $610,094.27$ & $476,051.56$ & $134,042.71$ \\
\hline 0.85 & $610,094.27$ & $509,562.24$ & $100,532.03$ \\
\hline 0.9 & $610,094.27$ & $543,072.92$ & $67,021.356$ \\
\hline 0.95 & $610,094.27$ & $576,583.59$ & $33,510.678$ \\
\hline 1 & $610,094.27$ & $610,094.27$ & 0 \\
\hline
\end{tabular}

Source: based on (The site of the energy service company "Ecological Systems" 2021).

These analytical representations of the linear dependences $E V A_{E S C O}$ and $E V A_{\text {customer }}$ on the contract price allow one to obtain the values of the investigated functions for any $\alpha$, taking into account that the following values of the value-added components are the input parameters in the calculations: $d=1 ; \mathrm{T}=8 ; K_{\mathrm{on}}=18 \%, W A C C=5 \%, R=10.5 \%$.

The environmental effect from the implementation of energy-saving measures (Table 1) can be calculated based on the data obtained as a result of modelling the value added created in the energy service market. At the same time, we proceed from the fact that $\mathrm{CO}_{2}$ emissions from combusted fuel are not only the main component of all anthropogenic greenhouse gas emissions but also their most accurately known part because, in all countries, fuel combustion is a subject of strict statistical reporting. $\mathrm{CO}_{2}$ emissions primarily depend on the amount of fuel used. The energy efficiency of fuel combustion is important for the energy sector, but it does not significan- 


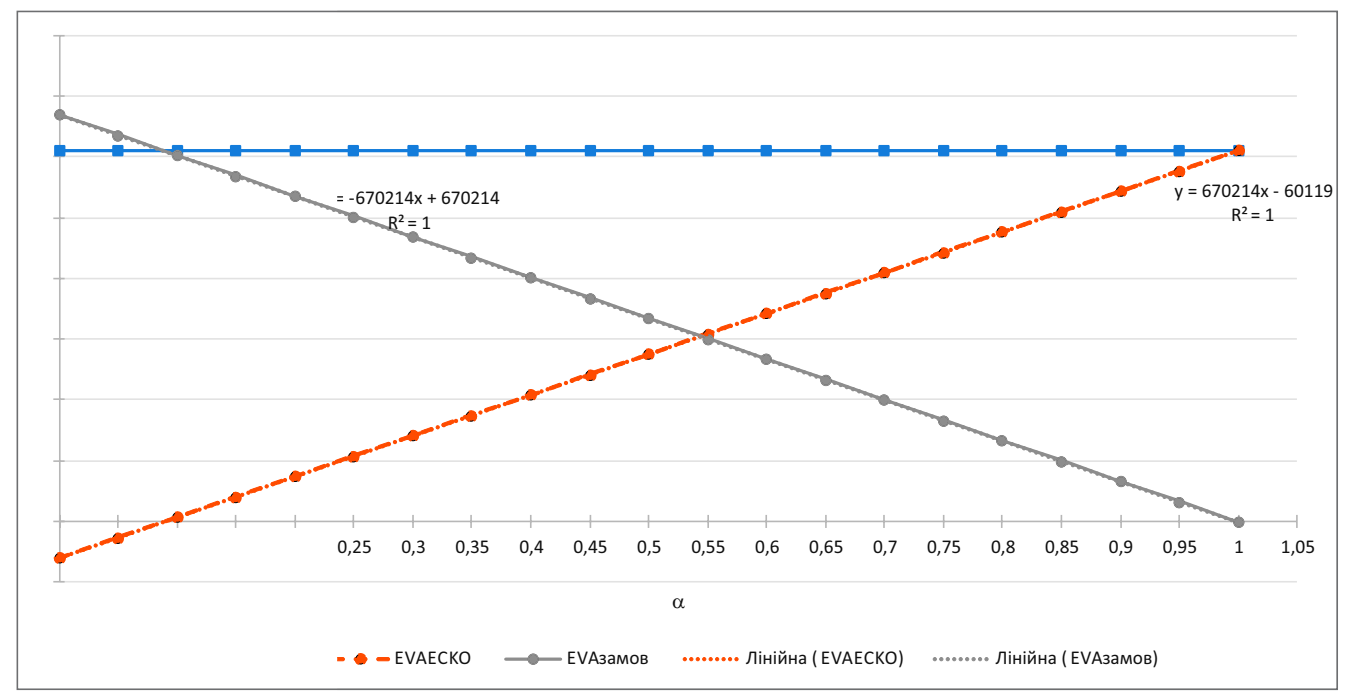

Fig. 1. Dependency graphs of functions $E V A_{\text {general }}, E V A_{E S C O}$ and $E V A_{\text {customer }}$ on the contract price $(\alpha)$ Source: obtained by the authors

Rys. 1. Wykresy zależności funkcji EVA general, $E V A_{E S C O}$ i $E V A_{\text {customer }}$ od ceny kontraktowej $(\alpha)$

tly affect $\mathrm{CO}_{2}$ emissions. The main factor is how much fuel is burned. As reference information for calculating $\mathrm{CO}_{2}$ emissions - equivalent when using energy resources - a conversion factor is used, specifically how much $\mathrm{CO}_{2}$ is released into the atmosphere when $1000 \mathrm{~m}^{3}$ of gas is burned: $k_{\mathrm{CO} 2 \text {-eqyl }}=1.85 \mathrm{t} / 1000 \mathrm{~m}^{3}$. The total value added created in the energy service market as a result of the implementation of energy efficient measures is 610094.27 UAH (Table 2) with an average gas price of $6000 \mathrm{UAH}$ per $\mathrm{m}^{3}$, saved $610,094.27 \mathrm{UAH} / 6000 \mathrm{UAH} / \mathrm{m}^{3}=101.68$ thousand $\mathrm{m}^{3}$ of gas. Then, the equivalent $\mathrm{CO}_{2}$ emissions is equal: $101.68 \cdot 1.85=186.851 \mathrm{t}$. The environmental effect obtained in the energy service market will be distributed between the energy service company and the customer depending on the contract price $\alpha$ in proportion to the added value they create (Table 2) and can be calculated in a similar way.

\section{Conclusions}

In the context of the transition to a climate-neutral development of the economy through the use of green technologies, an urgent issue is the substantiation of the ecological and economic effects of the energy service, which forms the added value of an energy service company. In addition, the approaches that are currently taking place are based on assessing the economic efficiency of energy service contracts using the methodology for calculating 
the net held value, which does not reflect all the realities of the modern energy service market and cannot be fully applied to the management of companies in the system of their cost-oriented management.

However, it is important to ensure the environmental effect created in the energy service market, which in the paradigm of sustainable development is one of its main components, by forming a methodological toolkit based on the indicators of the economic added value model, namely financial results and alternative sources of investment capital from energy-saving and environmental measures. In further studies, it is necessary to determine the peculiarities of modelling the value added created in the energy service market and improve the methodological basis for conducting an environmental and economic assessment of potential resource-saving projects.

\section{References}

Bertoldi et al. 2019 - Bertoldi, P., Boza-Kiss, B. and Toleikyte, A. 2019. Energy Service Market in the EU. Publications Office of the European Union, Luxembourg.

BorysiaK, O. and Brych, V. 2021. Methodological Approach to Assessing the Management Model of Promoting Green Energy Services in the Context of Development Smart Energy Grids. Financial and Credit Activity: Problems of Theory and Practice 4(39), pp. 302-309, DOI: 10.18371/fcaptp.v4i39.241319.

Borysova et al. 2021 - Borysova, T., Monastyrskyi, G., Borysiak, O. and Protsyshyn, Y. 2021. Priorities of Marketing, Competitiveness, and Innovative Development of Transport Service Providers under Sustainable Urban Development. Marketing and Management of Innovations 3, pp. 78-89, DOI: 10.21272/mmi.2021.3-07.

Boza-Kiss et al. 2019 - Boza-Kiss, B., Toleikyté, A. and Bertoldi, P. 2019. Energy Service Market in the EU - Status review and recommendations. Scientific and Technical Report. European ESCO Market Reports series. European Commission, Luxembourg.

Brych et al. 2020 - Brych, V., Manzhula, V., Borysiak, O., Liakhovych, G., Halysh, N. and Tolubyak, V. 2020. Communication Model of Energy Service Market Participants in the Context of Cyclic Management City Infrastructure. $202010^{\text {th }}$ International Conference on Advanced Computer Information Technologies (ACIT), pp. 678-681, DOI: 10.1109/ACIT49673.2020.9208902.

Brych et al. 2021 - Brych, V., Mykytyuk, P., Halysh, N., Borysiak, O., ZheKalo, G. and Sokol, M. 2021. Management Model of Energy Enterprises Innovative Development Within Physiological Working Conditions. Propósitos y Representaciones, 9(SPE3), 1173. [Online] http://revistas.usil.edu.pe/ index.php/pyr/article/view/1173 [Accessed: 2021-10-16].

Brych et al. 2021 - Brych, V., Zatonatska, T., Dluhopolskyi, O., Borysiak, O. and Vakun, O. 2021. Estimating the Efficiency of the Green Energy Services' Marketing Management Based on Segmentation. Marketing and Management of Innovations 3, pp. 188-198, DOI: 10.21272/mmi.2021.3-16.

DAVYDOv, O.I. 2017. Models of value added of enterprises: economic content and features of construction. Scientific Bulletin of the International Humanities University, 28, pp. 167-172. [Online] http://nbuv. gov.ua/j-pdf/Nvmgu_eim_2017_28_35.pdf [Accessed: 2021-11-05].

Fraser, M. and Montross, C. 1998. Energy service companies - the sky's the limit! [Online] https:// www.semanticscholar.org/paper/Energy-service-companies-The-sky's-the-limit-Fraser-Montross/ 42c8a2c8507421fc50ecc2256e3a709ff56f837b [Accessed: 2021-11-05]. 
Hansen et al. 2009 - Hansen, S.J., Bertoldi, P. and Langlois, P. 2009. ESCOs Around the World: Lessons Learned in 49 Countries. Lilburn, The Fairmont Press.

Kovtoniuk et al. 2021 - Kovtoniuk, K., Molchanova, E., Dluhopolskyi, O., Weigang, G. and PianKOVA, O. 2021. The factors' analysis of influencing the development of digital trade in the leading countries. $11^{\text {th }}$ International Conference on Advanced Computer Information Technologies (September 15-17, 2021). Deggendorf, Germany, pp. 290-293.

Koziuk et al. 2020 - Koziuk, V., HAYda, Y., Dluhopolskyi, O. and Kozlovskyi, S. 2020. Ecological performance: ethnic fragmentation versus governance quality and sustainable development. Problemy Ekorozwoju / Problems of Sustainable Development 15(1), pp. 53-64.

Law of Ukraine "On the introduction of new investment opportunities, ensuring the rights and legitimate interests of business entities for large-scale energy modernization”, April 9, 2015, №327-VIII.

Liakhovych et al. 2021 - Liakhovych, G., Kupchak, V., Borysiak, O., Huhul, O., Halysh, N., Brych, V. and SoкоL, M. 2021. Innovative human capital management of energy enterprises and the role of shaping the environmental behavior of consumers of green energy based on the work of smart grids. Propósitos y Representaciones 9(SPE3), 1293. [Online] https://revistas.usil.edu.pe/index.php/ pyr/article/view/1293 [Accessed: 2021-10-26].

Maki et al. 2021 - Maki, E., Kannari, L., Hannula, I. and ShemeikKa, J. 2021. Decarbonisation of a district heating system with a combination of solar heat and bioenergy: A techno-economic case study in the Northern European context. Renewable Energy 175, pp. 1174-1199, DOI: 10.1016/j.renene.2021.04.116.

MiLINCHUK, O.V. 2016. Value-Based Management Effectiveness: Key Indicators. Bulletin of Zhytomyr State Technological University 1, pp. 86-96.

Penate-Valentín et al. 2021 - Penate-Valentín, M.C., Sanchez-Carreira, M.C. and Pereira, A. 2021 The promotion of innovative service business models through public procurement. An analysis of Energy Service Companies in Spain. Sustainable Production and Consumption 27, pp. 1857-1868.

Report extract ESCO contracts. 2021. [Online] https://www.iea.org/reports/energy-service-companies-escos-2/esco-contracts [Accessed: 2021-11-10].

Romanenko, O.V. 2013. Strategic enterprise value analysis. Scientific notes of the National University "Ostroh Academy": Economics series 21, pp. 256-261.

SotNIK, I.N. and MAZIN, Y.A. 2015. Energy service companies in the market of resource-saving goods and services in Ukraine. Actual economic problems 1, pp. 321-328.

The site of the energy service company "Ecological Systems". [Online] https://www.ecosys.com.ua [Accessed: 2021-11-10].

Urge-Vorsatz et al. 2007 - Urge-Vorsatz, D., Koppel, S. and Liang, C. 2007. An Assessment of Energy Service Companies (ESCOs) Worldwide. Central European University. [Online] www.worldenergy.org [Accessed: 2021-09-23].

Van Der Kam et al. 2019 - Van Der Kam, M., Peters, A., Van Sark, W. and Alkemade, F. 2019. Agent-based modelling of charging behaviour of electric vehicle drivers. Journal of Artificial Societies and Social Simulation, 22(4), 7, DOI: 10.18564/jasss.4133.

Vence, X. and Pereira, A. 2019. Eco-innovation and Circular Business Models as drivers for a circular economy. Contaduría y Administración 64(1), pp. 1-19.

Volkov, D.L. 2008. Value-Based Management Theory: Financial and Accounting Aspects. SPb.: Medical High School. 


\section{Modelowanie wpływu efektu środowiskowego i ekonomicznego na wartość dodaną na rynku usług energetycznych}

\section{Streszczenie}

Wprowadzenie zasad służących oszczędzaniu energii i zasobów ma pozytywny wpływ na środowisko i jest jednym z elementów zrównoważonego rozwoju na poziomie makro. $Z$ kolei na poziomie mikro takie działania prowadzą do systematycznego obniżania kosztów produkcji firm, a tym samym poszerzają obszar ich bezpieczeństwa ekonomicznego i finansowego.

Ten artykuł poświęcony jest opracowaniu metodologii służącej modelowaniu efektu środowiskowego i ekonomicznego na wartość dodaną na rynku usług energetycznych. Aby to było możliwe, omówiono specyfikę i elementy umowy o świadczenie usług energetycznych.

Ustalono, że jednym ze wskaźników takiej umowy jest wskaźnik efektywności energetycznej i ekologiczności działań przedsiębiorstwa usług energetycznych mający wpływ na wartość kontraktu.

Przeprowadzano analizę istniejących modeli wartości dodanej funkcjonujących na rynku usług energetycznych. Model ekonomicznej wartości dodanej jest podstawą do modelowania efektu ekologicznego i ekonomicznego. Uzasadnienie jest takie, że taką wartością dodaną jest modyfikacja wskaźnika zysku ekonomicznego, który mierzy wynik finansowy przedsiębiorstwa, biorąc pod uwagę nie tylko koszty księgowe, ale także koszty alternatywne zainwestowanego kapitału na działania w zakresie efektywności energetycznej i ochrony środowiska.

SŁowA KLUCZOwE: zrównoważony rozwój, zielona energia, wartość dodana, rynek energii, przedsiębiorstwa usług energetycznych (ESCO) 